\title{
Dithranol downregulates expression of Id1 mRNA in human keratinocytes in vitro
}

\author{
C. Ronpirin ${ }^{1}$ and T. Tencomnao ${ }^{2}$ \\ ${ }^{1}$ Department of Preclinical Science, Faculty of Medicine, \\ Thammasat University, Pathumthani, Thailand \\ ${ }^{2}$ Center for Excellence in Omics - Nano Medical Technology Development Project, \\ Department of Clinical Chemistry, Faculty of Allied Health Sciences, \\ Chulalongkorn University, Bangkok, Thailand \\ Corresponding author: C. Ronpirin \\ E-mail: cronpirin@yahoo.com
}

Genet. Mol. Res. 11 (3): 3290-3297 (2012)

Received November 23, 2011

Accepted June 25, 2012

Published September 12, 2012

DOI http://dx.doi.org/10.4238/2012.September.12.12

\begin{abstract}
The precise causes of psoriasis, a chronic skin disorder characterized by hyperproliferation of keratinocytes and incomplete keratinization, are unclear. It is known that expression of helix-loop-helix transcription factor Id1, which functions as an inhibitor of differentiation, is upregulated in psoriatic skin. We investigated the effect of the antipsoriatic drug dithranol on mRNA and protein expression levels of Id1 in the HaCaT keratinocyte cell line. Cultured HaCaT cells were treated with $0-0.5 \mu \mathrm{g} / \mathrm{mL}$ dithranol for $30 \mathrm{~min}$. After 2 and $4 \mathrm{~h}$, total cellular RNA and total proteins were isolated from $\mathrm{HaCaT}$ cells, and quantitative real-time reverse transcriptase (RT-PCR) and Western blot were used to determine the mRNA and protein levels of Id1, respectively. Changes in normalized Id $1 \mathrm{mRNA}$ levels were observed only after $4 \mathrm{~h}$ of dithranol treatment. There was reduced expression of Id1 mRNA transcripts in the $\mathrm{HaCaT}$ cells treated with $0.1 \mu \mathrm{g} / \mathrm{mL}$ dithranol, but the reduction was not significant. The expression of Id1 mRNA was significantly downregulated (almost $50 \%$ ) when 0.25 or $0.5 \mu \mathrm{g} / \mathrm{mL}$ dithranol was applied to the $\mathrm{HaCaT}$ cells. However, the normalized Id 1 protein levels were not significantly
\end{abstract}


affected. The molecular mechanisms underlying this finding should be investigated further to help determine the therapeutic action of this drug.

Key words: Psoriasis; Dithranol; Id1; Gene expression; HaCaT

\section{INTRODUCTION}

Psoriasis is a chronic, recurring inflammatory disease that affects approximately $1.5-2 \%$ of the population, possibly owing to conserved genetic and environmental susceptibilities worldwide (Jacobson et al, 2011). The molecular mechanism underlying the pathophysiology of psoriasis is not well understood; therefore, researchers have attempted to study genes and molecules, which may provide insight into understanding the cause of psoriasis. Because psoriasis is a disease without a lasting cure, knowing its precise cause will eventually shed light on better therapeutic approaches.

In particular, inhibitor of differentiation-1 (Id1), which stimulates cell proliferation, inhibits cell differentiation, and activates angiogenesis (Lister et al., 1995; Lyden et al., 1999; Ling et al., 2005), has been demonstrated to be important in the proliferation and survival of certain cells and tissues such as cancer cells (Ouyang et al., 2002; Schindl et al., 2003; Schoppmann et al., 2003; Wong et al., 2004; Cheng et al., 2011) and synovial tissues from patients with rheumatoid arthritis (Sakurai et al., 2001). Id1 is a member of a group of helixloop-helix (HLH) proteins that act as dominant-negative factors, forming homo- and heterodimers with other basic HLH transcription factors (Benezra et al., 1990; Ristow, 1996). Apparently, the proteins in this group are deficient in the basic residues adjacent to the HLH domain, which binds to E-box-containing DNA regions (Massari and Murre, 2000). Hence, the resulting Id-bHLH heterodimers are unable to bind to DNA.

Of great interest, Id1 was recently demonstrated to contribute to the hyperproliferation of keratinocytes via the enhancement of cell cycle progression, removal of cell cycle inhibition, and increase in keratin production (Hamajima et al., 2010). With regard to psoriasis, Id1 messenger RNA (mRNA) and protein levels were found to be highly expressed in psoriatic involved skin (Bjorntorp et al., 2003). Consistently, Id1 mRNA was reported to be upregulated in psoriatic involved skin but not in psoriatic uninvolved skin (Mark et al., 2006). Very recently, we revealed that the normalized level of Id1 transcripts in psoriatic patients was approximately twofold higher than that in controls (Ronpirin et al., 2010). Thus, Id1 may be a potential biomarker associated with the pathophysiology of psoriasis. We wondered whether antipsoriatic drugs such as dithranol (anthralin or 1,8-dihydroxy-9-anthrone), which has been widely used as a topical therapy (Pavithran 2001; Afifi et al., 2005; Kamili and Menter, 2009), could modulate the expression of the Id1 gene. Specifically, we hypothesized that dithranol could reduce gene expression. The objective of this study was to investigate the molecular role of dithranol on the mRNA and protein expression levels of Id 1 in the HaCaT keratinocyte cell line.

\section{MATERIAL AND METHODS}

\section{Cell culture}

The human keratinocyte cell line HaCaT was purchased from CLS-Cell Lines Service (Eppelheim, Germany) (Boukamp et al., 1988). The cells were cultured in Dulbecco's modified Eagle's 
medium (DMEM; HyClone, Logan, UT, USA) with 10\% fetal bovine serum (FBS; HyClone), 100 $\mathrm{U} / \mathrm{mL}$ penicillin, $100 \mu \mathrm{g} / \mathrm{mL}$ streptomycin, and $0.25 \mu \mathrm{g} / \mathrm{mL}$ amphotericin B (Invitrogen, Carlsbad, $\mathrm{CA}$, USA). The cells were maintained at $37^{\circ} \mathrm{C}$ in a humidified atmosphere with $5 \% \mathrm{CO}_{2}$.

\section{Dithranol treatment}

Dithranol treatment was conducted according to a published procedure (Farkas et al., 2001) with slight modification (Tencomnao et al., 2009; Ronpirin and Tencomnao, 2012). Dithranol was purchased from Sigma (St. Louis, MO, USA) and was always newly dissolved in acetone and used immediately. Briefly, cultured $\mathrm{HaCaT}$ cells at approximately $90 \%$ confluence on a $60-\mathrm{mm}$ plate were washed with phosphate-buffered saline under sterile conditions and incubated for $30 \mathrm{~min}$ at $37^{\circ} \mathrm{C}$ in a humidified atmosphere $\left(5 \% \mathrm{CO}_{2}\right)$ with increasing concentrations of dithranol $(0.1,0.25$, and $0.5 \mu \mathrm{g} / \mathrm{mL})$ in DMEM containing $0.5 \%$ FBS. Control cells were treated with the acetone only $(0 \mu \mathrm{g} / \mathrm{mL}$ dithranol $)$ or left untreated. After dithranol treatment, cells were washed with phosphate-buffered saline and cultured in DMEM containing $10 \% \mathrm{FBS}$ for 2 and $4 \mathrm{~h}$ at $37^{\circ} \mathrm{C}$ in a humidified atmosphere at $5 \% \mathrm{CO}_{2}$ before isolation of total cellular RNA and proteins for subsequent experiments.

\section{Total RNA extraction, complementary DNA (cDNA) synthesis, and quantitative real-time polymerase chain reaction $(\mathrm{PCR})$}

Total cellular RNA isolation was performed using the Trizol reagent (Invitrogen) following the manufacturer protocol with minor modifications (Ronpirin and Tencomnao, 2012). In brief, the total RNA was quantified spectrophotometrically at $260 \mathrm{~nm}$. Before quantitative real-time reverse transcriptase-PCR (RT-PCR), approximately $1 \mu \mathrm{g}$ total RNA was treated with deoxyribonuclease I (Invitrogen) according to the manufacturer protocol for $15 \mathrm{~min}$ at $25^{\circ} \mathrm{C}$. Approximately 250 ng deoxyribonuclease I-treated RNA was used for first-strand cDNA synthesis using an ImProm-II ${ }^{\mathrm{TM}}$ Reverse Transcription System (Promega, Madison, WI, USA) with oligo $(\mathrm{dT})_{17}$ primer following manufacturer instructions. Reverse transcription was carried out at $50^{\circ} \mathrm{C}$ for $60 \mathrm{~min}$. Then RT-PCR was performed on the StepOnePlus ${ }^{\mathrm{TM}}$ (Applied Biosystems, Foster City, CA, USA) using TaqMan ${ }^{\circledR}$ Universal PCR Master Mix and TaqMan ${ }^{\circledR}$ Gene Expression Assays probe and primer mix (Applied Biosystems), based on the manufacturer protocol as previously described (Ronpirin and Tencomnao, 2012). The assay identification numbers of Id1 and ubiquitin C (UBC) were Hs00704053 and Hs00824723, respectively. Amplification reactions in triplicate for each sample were carried out, and the results were normalized to the UBC gene expression level. An analysis of relative gene expression data was performed using the Applied Biosystems StepOne ${ }^{\mathrm{TM}}$ Real-time PCR v. 2.0 Software with respect to the fold change in studied gene expression normalized to endogenous control. The data for each dithranol treatment represented the fold change in normalized mRNA expression relative to that at $0 \mu \mathrm{g} / \mathrm{mL}$ dithranol. The relative expression in fold change was arbitrarily set at 1 .

\section{Total protein preparation and Western blot analysis}

Total protein preparation and Western blotting were carried out as previously described (Ronpirin and Tencomnao, 2012). In short, the total protein was isolated from the HaCaT cells 
using Nonidet-P40 lysis buffer (1\% Nonidet-P40, $20 \mathrm{mM}$ Tris, pH 7.4, $150 \mathrm{mM} \mathrm{NaCl}, 3 \%$ glycerol, $1.5 \mathrm{mM}$ ethylenediaminetetraacetic acid) with protease inhibitors. Protein concentrations were measured following the Bradford (1976) method using a protein assay kit (Bio-Rad, Hercules, CA, USA) and bovine serum albumin (Sigma) as a standard. The primary antibody solutions for Western blotting were a 1:2000 dilution of polyclonal rabbit anti-Id1 (Cat. No. sc-488, Santa Cruz Biotechnology, Santa Cruz, CA, USA) and a 1:4000 dilution of polyclonal rabbit anti-glyceraldehyde-3-phosphate dehydrogenase (GAPDH; Cat. No. sc-25778, Santa Cruz Biotechnology). The secondary antibody solution was a 1:5000 dilution of an affinity purified goat anti-rabbit IgG coupled to horseradish peroxidase (Cat. No. 7074, Cell Signaling Technology, Beverly, MA, USA). The immunoreactive protein bands were detected using the LumiGLO reagent and peroxide (Cell Signaling) for Id1 (15 kDa) and GAPDH (37 kDa) and quantitated densitometrically using a 1-D Multi-Lane Densitometry program in an AlphaImager 2000 (Alpha Innotech Corp., San Leandro, CA, USA). Relative densities of immunoreactive bands were normalized to the density of corresponding bands for GAPDH.

\section{Statistical analysis}

All results are expressed as means \pm SEM. Statistical comparisons were performed using one-way analysis of variance with the Dunnett multiple comparison post hoc test. Data were regarded as statistically significant at $\mathrm{P}<0.05$.

\section{RESULTS}

\section{Determination of the Id1 mRNA using quantitative RT-PCR}

We determined the in vitro effect of dithranol on the expression of Id1 mRNA using a quantitative RT-PCR technique with the housekeeping gene UBC as an internal control. The results of the quantitative RT-PCR are shown in Figure 1. After $2 \mathrm{~h}$ of dithranol treatment, normalized Id1 mRNA transcripts of $\mathrm{HaCaT}$ cells were not significantly altered as dithranol concentration increased. Nevertheless, changes in normalized Id1 mRNA levels of HaCaT cells were observed when analysis was performed after $4 \mathrm{~h}$ of dithranol treatment. As compared to $0 \mu \mathrm{g} / \mathrm{mL}$ dithranol concentration (acetone-treated cells), treatment of $\mathrm{HaCaT}$ cells with $0.1 \mu \mathrm{g} /$ $\mathrm{mL}$ dithranol revealed no statistical significance, but a tendency of reduced expression of Id1 mRNA was noticed. The expression of Id 1 mRNA transcripts was significantly downregulated by $50 \%$ when a concentration of either 0.25 or $0.5 \mu \mathrm{g} / \mathrm{mL}$ dithranol was applied to the cells (P $<0.05)$. Taken together, the downregulation effect of dithranol on the expression of Id $1 \mathrm{mRNA}$ transcripts was concentration-dependent in the $\mathrm{HaCaT}$ cells.

\section{Determination of the Id1 protein using Western blot technique}

In addition to investigating Id 1 mRNA transcripts, we further measured the expression levels of the Id1 protein using a Western blot technique with polyclonal antibody specific to the Id1 protein. Using the GAPDH protein as a ubiquitous housekeeping gene, we found no significant changes in normalized Id1 protein levels regardless of dithranol concentration and the time elapsed after treatment (Figure 2). 


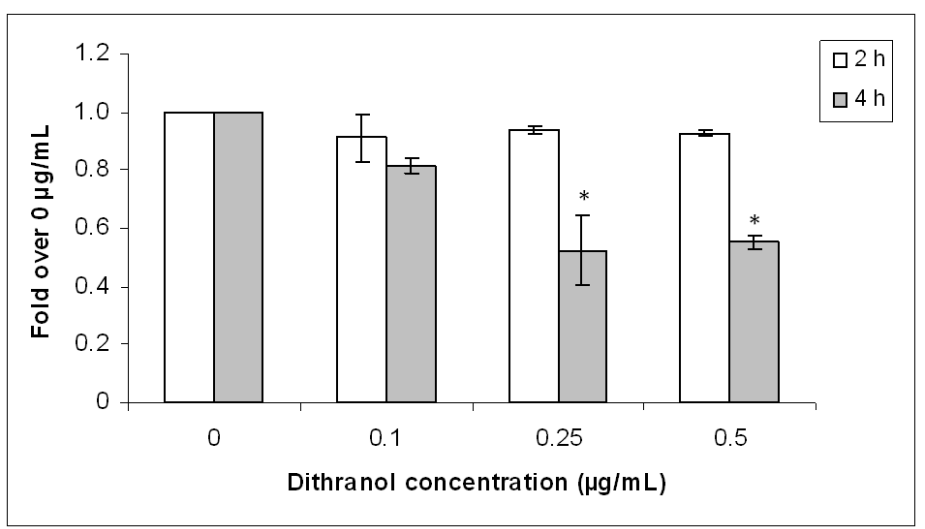

Figure 1. Quantitative real-time RT-PCR analysis of Id1 expression in HaCaT cells treated with increasing dithranol concentrations $(0,0.1,0.25$, and $0.5 \mu \mathrm{g} / \mathrm{mL})$ for 2 and $4 \mathrm{~h}$. Average fold over expression at $0 \mu \mathrm{g} / \mathrm{mL}$ dithranol. *Indicating a statistically significant difference $(\mathrm{P}<0.05)$.

A
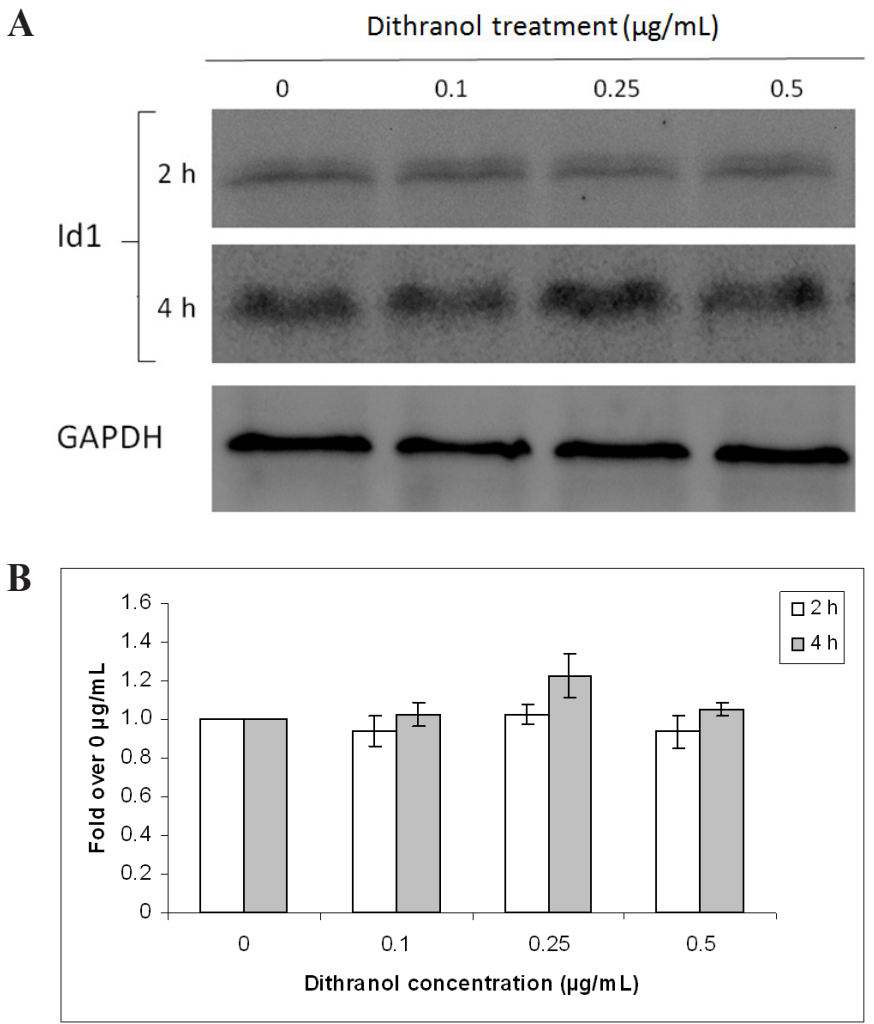

Figure 2. Western blot analysis of $\mathrm{Id} 1$ in $\mathrm{HaCaT}$ cells treated with increasing dithranol concentrations $(0,0.1$, 0.25 , and $0.5 \mu \mathrm{g} / \mathrm{mL}$ ) for 2 and $4 \mathrm{~h}$. A. Immunodetected protein band for Id1 and glyceraldehyde 3-phosphate dehydrogenase (GAPDH). B. Average fold over expression at $0 \mu \mathrm{g} / \mathrm{mL}$ dithranol for the Id 1 protein. 


\section{DISCUSSION}

We hypothesized that the antipsoriatic drug dithranol could reduce the expression of the Id1 gene in an experimental in vitro model using the HaCaT cell line because Id1 is an elevated biomarker in psoriasis (Bjorntorp et al., 2003; Mark et al., 2006; Ronpirin et al., 2010). This cell line, originally documented by Boukamp et al. (1988), is believed to be an appropriate cellular model of psoriasis based on previous reports (Farkas et al., 2001; Tencomnao et al., 2009; George et al., 2010; Saelee et al., 2011; Ronpirin and Tencomnao, 2012). Hamajima et al. (2010) demonstrated the role of Id1 in the hyperproliferation of keratinocytes, possibly via the nuclear factor-kappa B signaling pathway. Notably, we revealed that the nuclear factorkappa B signaling network might be a target for antipsoriatic herbal drugs (Saelee et al., 2011).

In this study, we used quantitative RT-PCR and Western blot to determine mRNA and protein levels, respectively. We found that the expression of Id1 mRNA transcripts was significantly decreased by $50 \%$ when a concentration of either 0.25 or $0.5 \mu \mathrm{g} / \mathrm{mL}$ dithranol was applied to the HaCaT cells $(\mathrm{P}<0.05)$. We detected no significant change in the level of Id1 mRNA when treating the HaCaT cells with $0.1 \mu \mathrm{g} / \mathrm{mL}$ dithranol. Therefore, the inhibitory effect of dithranol on the expression of Id1 mRNA transcripts was dose-dependent in the HaCaT cells. Nevertheless, the results of Western blotting were contrary to those of our mRNA study. This disagreement might be due to several factors. First, the 2 techniques relied on different housekeeping genes: UBC and GAPDH were used for RT-PCR and Western blotting, respectively. In fact, at least 3 genes should be included as housekeeping genes for this kind of study. Second, mRNA levels and protein levels are often controlled independently.

Several mRNA and protein comparisons have demonstrated a varied correlation between expression levels or changes in protein and mRNA. For instance, recent research examining gene expression profiles in 23 human cell lines demonstrated mean correlation coefficients between mRNA and corresponding protein levels in the range 0.20 to 0.25 , and significant correlations were found in only one-third of the examined mRNA species and corresponding proteins (Gry et al., 2009). Another correlation study on human circulation monocytes showed significant correlation between average mRNA and average protein expression levels with a correlation coefficient of approximately 0.3 (Guo et al., 2008). No significant relationship between specific mRNA and corresponding protein levels has been found in human prostate cancers (Lichtinghagen et al., 2002). These findings suggest that mRNA expression might be occasionally valuable but is undoubtedly far from perfect for predicting protein expression levels.

In normal human keratinocytes, the expression of Id1 is activated by all-trans retinoic acid (Villano and White, 2006). We found, however, that the Id1 gene is downregulated by the effect of dithranol in the HaCaT cell line, the cellular model of psoriasis. This result suggests that Id1 gene expression can be modulated, and this modification can be applied to the development of therapy if a molecular target such as Id1 is a biomarker associated with pathogenesis. The concept of using Id 1 as a novel therapeutic target is of great interest in our present research. For example, the nontoxic exogenous agent cannabidiol has been reported to decrease Id1 expression significantly in metastatic breast cancer cells, leading to the downregulation of tumor aggressiveness (McAllister et al., 2007, 2011). Downregulation of the Id1 gene by small interfering RNA in in vivo and in vitro prostate cancer has been shown to suppress cell proliferation and induce apoptosis and senescence in PC3 cells. It also has a preventive effect against the development of prostate cancer in a mouse model (Ling et al., 2011). In conclusion, 
our study found that dithranol has a downregulation effect on Id1 mRNA in HaCaT cells. The molecular mechanisms underlying this finding await further exploration.

\section{ACKNOWLEDGMENTS}

C. Ronpirin and T. Tencomnao were recipients of Thammasat University and Chulalongkorn University Centenary Academic Development Project grants, respectively.

\section{REFERENCES}

Afifi T, de GG, Huang C and Zhou Y (2005). Topical therapies for psoriasis: evidence-based review. Can. Fam. Physician 51: $519-525$.

Benezra R, Davis RL, Lockshon D, Turner DL, et al. (1990). The protein Id: a negative regulator of helix-loop-helix DNA binding proteins. Cell 61: 49-59.

Bjorntorp E, Parsa R, Thornemo M, Wennberg AM, et al. (2003). The helix-loop-helix transcription factor Id1 is highly expressed in psoriatic involved skin. Acta Derm. Venereol. 83: 403-409.

Boukamp P, Petrussevska RT, Breitkreutz D, Hornung J, et al. (1988). Normal keratinization in a spontaneously immortalized aneuploid human keratinocyte cell line. J. Cell. Biol. 106: 761-771.

Bradford MM (1976). A rapid and sensitive method for the quantitation of microgram quantities of protein utilizing the principle of protein-dye binding. Anal. Biochem. 72: 248-254.

Cheng YJ, Tsai JW, Hsieh KC, Yang YC, et al. (2011). Id1 promotes lung cancer cell proliferation and tumor growth through Akt-related pathway. Cancer Lett. 307: 191-199.

Farkas A, Kemeny L, Szony BJ, Bata-Csorgo Z, et al. (2001). Dithranol upregulates IL-10 receptors on the cultured human keratinocyte cell line HaCaT. Inflamm. Res. 50: 44-49.

George SE, Anderson RJ, Cunningham A, Donaldson M, et al. (2010). Evaluation of a range of anti-proliferative assays for the preclinical screening of anti-psoriatic drugs: a comparison of colorimetric and fluorimetric assays with the thymidine incorporation assay. Assay Drug Dev. Technol. 8: 389-400.

Gry M, Rimini R, Stromberg S, Asplund A, et al. (2009). Correlations between RNA and protein expression profiles in 23 human cell lines. BMC Genomics 10: 365.

Guo Y, Xiao P, Lei S, Deng F, et al. (2008). How is mRNA expression predictive for protein expression? A correlation study on human circulating monocytes. Acta Biochim. Biophys. Sin. 40: 426-436.

Hamajima Y, Komori M, Preciado DA, Choo DI, et al. (2010). The role of inhibitor of DNA-binding (Id1) in hyperproliferation of keratinocytes: the pathological basis for middle ear cholesteatoma from chronic otitis media. Cell Prolif. 43: 457-463.

Jacobson CC, Kumar S and Kimball AB (2011). Latitude and psoriasis prevalence. J. Am. Acad. Dermatol. 65: 870-873.

Kamili QU and Menter A (2009). Topical treatment of psoriasis. Curr. Probl. Dermatol. 38: 37-58.

Lichtinghagen R, Musholt PB, Lein M, Römer A, et al. (2002). Different mRNA and protein expression of matrix metalloproteinases 2 and 9 and tissue inhibitor of metalloproteinases 1 in benign and malignant prostate tissue. Eur. Urol. 42: 398-406.

Ling MT, Lau TC, Zhou C, Chua CW, et al. (2005). Overexpression of Id-1 in prostate cancer cells promotes angiogenesis through the activation of vascular endothelial growth factor (VEGF). Carcinogenesis 26: 1668-1676.

Ling YX, Tao J, Fang SF, Hui Z, et al. (2011). Downregulation of Id1 by small interfering RNA in prostate cancer PC3 cells in vivo and in vitro. Eur. J. Cancer Prev. 20: 9-17.

Lister J, Forrester WC and Baron MH (1995). Inhibition of an erythroid differentiation switch by the helix-loop-helix protein Id1. J. Biol. Chem. 270: 17939-17946.

Lyden D, Young AZ, Zagzag D, Yan W, et al. (1999). Id1 and Id3 are required for neurogenesis, angiogenesis and vascularization of tumour xenografts. Nature 401: 670-677.

Mark EB, Jonsson M, Asp J, Wennberg AM, et al. (2006). Expression of genes involved in the regulation of p16 in psoriatic involved skin. Arch. Dermatol. Res. 297: 459-467.

Massari ME and Murre C (2000). Helix-loop-helix proteins: regulators of transcription in eucaryotic organisms. Mol. Cell Biol. 20: 429-440.

McAllister SD, Christian RT, Horowitz MP, Garcia A, et al. (2007). Cannabidiol as a novel inhibitor of Id-1 gene expression in aggressive breast cancer cells. Mol. Cancer Ther. 6: 2921-2927. 
McAllister SD, Murase R, Christian RT, Lau D, et al. (2011). Pathways mediating the effects of cannabidiol on the reduction of breast cancer cell proliferation, invasion, and metastasis. Breast Cancer Res. Treat. 129: 37-47.

Ouyang XS, Wang X, Lee DT, Tsao SW, et al. (2002). Over expression of ID-1 in prostate cancer. J. Urol. 167: 2598-2602. Pavithran K (2001). Psoriasis: topical treatment. Indian J. Dermatol. Venereol. Leprol. 67: 85.

Ristow HJ (1996). Studies on stimulation of DNA synthesis with epidermal growth factor and insulin-like growth factor-I in cultured human keratinocytes. Growth Regul. 6: 96-109.

Ronpirin C and Tencomnao T (2012). Effects of the antipsoriatic drug dithranol on E2A and caspase-9 gene expression in vitro. Genet. Mol. Res. 11: 412-420.

Ronpirin C, Achariyakul M, Tencomnao T, Wongpiyabovorn J, et al. (2010). Up-regulation of Id1 in peripheral blood of psoriatic patients. Genet. Mol. Res. 9: 2239-2247.

Saelee C, Thongrakard V and Tencomnao T (2011). Effects of Thai medicinal herb extracts with anti-psoriatic activity on the expression on NF-kappaB signaling biomarkers in HaCaT keratinocytes. Molecules 16: 3908-3932.

Sakurai D, Yamaguchi A, Tsuchiya N, Yamamoto K, et al. (2001). Expression of ID family genes in the synovia from patients with rheumatoid arthritis. Biochem. Biophys. Res. Commun. 284: 436-442.

Schindl M, Schoppmann SF, Strobel T, Heinzl H, et al. (2003). Level of Id-1 protein expression correlates with poor differentiation, enhanced malignant potential, and more aggressive clinical behavior of epithelial ovarian tumors. Clin. Cancer Res. 9: 779-785.

Schoppmann SF, Schindl M, Bayer G, Aumayr K, et al. (2003). Overexpression of Id-1 is associated with poor clinical outcome in node negative breast cancer. Int. J. Cancer 104: 677-682.

Tencomnao T, Ronpirin C, Prasansuklab A and Poovorawan Y (2009). Decreased EGFR mRNA expression in response to antipsoriatic drug dithranol in vitro. Afr. J. Biotechnol. 8: 3141-3146.

Villano CM and White LA (2006). Expression of the helix-loop-helix protein inhibitor of DNA binding-1 (ID-1) is activated by all-trans retinoic acid in normal human keratinocytes. Toxicol. Appl. Pharmacol. 214: 219-229.

Wong YC, Wang X and Ling MT (2004). Id-1 expression and cell survival. Apoptosis 9: 279-289. 